\title{
Motivators of Students' Persistence on Distance Learning Programmes in Ethno-Religious Crisis States in Nigeria: Implications for Counselling
}

\author{
Fidel O. Okopi, Joshua Pindar \\ National Open University of Nigeria, Lagos, Nigeria \\ Email: okopifidel@yahoo.co.uk, j_pindar2006@yahoo.ca \\ Received 9 July 2014; revised 5 August 2014; accepted 1 September 2014 \\ Copyright (C) 2014 by authors and Scientific Research Publishing Inc. \\ This work is licensed under the Creative Commons Attribution International License (CC BY). \\ http://creativecommons.org/licenses/by/4.0/

(c) (i) Open Access

\section{Abstract}

This study determines students' persistence on distance learning programmes despite ethno-religious crisis in twelve Northern States in Nigeria. States selected for the study are Borno, Yobe, Adamawa, Taraba, Gombe, Bauchi, Jos, Kaduna, Kano, Niger, Kogi and Sokoto states that have suffered the worst ethno-religious crisis from 2009 to date. A survey design via ex post facto was adopted for the study. Samples for the study were distance learners, (200 to 400 levels) who registered for the 2012/2013 examination, and 480 were selected from the 12 Study Centres through purposeful, and stratified random sampling techniques. Data for the study were collected through a rating scale which was administered and collected on the spot by the research assistants. Participants were asked to rate the shortlisted factors-(Intrinsic-Personal and Extrinsic-support network factors) according to their levels of perceived significant influence on why they persisted on their programmes of study, despite the ethno-religious crisis. Experts in the Directorate of Learner Support Services were used to validate the content and face validities of the instrument while test-retest reliability method was used and Cronbach Alfa 0.78 was established. Descriptive statistics and Pearson Moment Correlations Coefficient analyses were used to determine the relative rating of each motivator. The findings were intrinsic motivators like: desire to complete the programme was rated highest followed by desire for personal growth and faith in God. The least motivator was, study centre learning environment, followed by security provided at the centre and Tutorial facilitators' responses or feedback. The Pearson Moment Correlations Coefficient analysis indicated 0.83 level of relationship between extrinsic and extrinsic motivators. Recommendations were proffered at the end of the study and implications for counselling were discussed. 


\section{Keywords}

\section{Motivators, Persistence, Distance, Learning, Ethno-Religious, Crisis, Counselling}

\section{Introduction}

The study investigates the influence of perceived motivators responsible for students' persistence on distance learning programmes in an ethno-religious crisis ridden environment being experienced in 12 states in North West, North East and North Central Geo-political zones of Nigeria. Recently Nigeria has been grappling with recurrent religious and ethno-religious conflicts especially from the late eighties, precisely in 1987. The orgies of violence precipitated by inter and intra religious, ethno-religious or inter-ethnic conflict have become a recurrent phenomenon in Africa. In Nigeria, especially in Northern part of the country, ethno religious conflict has assumed a dreadful dimension that the Federal Government of Nigeria declared a state of emergency in three states of Borno, Yobe and Adamawa in May 2013.

Ethno-religious conflict fractionizes the society, destroys infrastructure, services, assets and livelihoods, displaces populations, breaks social cohesion, institutions and norms and also creates fear and distrust. The large scale destruction of lives, houses, places of worship and shops forced a large number of people in the affected areas to be displaced. Many people relocated to their normal places of abode or even outside their state of origin for their safety. According to Human Rights Watch as cited by Ndujihe (2013), between July and December 2010, at least 85 people were killed in some 35 separate incidents while 2011, at least 550 dead were recorded in some 115 separate incidents. In 2012, eight hundred and fifteen people died in some 275 incidents in 12 states in the Northern and Central states including Abuja in Nigeria.

The ethno-religious crisis has not only affected the smooth operations of National Open University Nigeria study centres located in these states but has resulted in the death of some students. For example in Damaturu Study Centre, two distance learners were killed while five distance learners of Maiduguri Study Centre were killed. This resulted in the relocation of many students of the study centres to other much safer parts of these states and the country. In some of these states affected by this crisis, telephone services which are vital modes of communication between distance learners and the study centres were disrupted through the destruction of critical telecommunication equipment. Some operators of Internet Cafes closed down their business centres and fled the town. Banking services were suspended for some time and their staff relocated to other safer parts of the country at the height of the crisis. In addition, it is the restriction of movement in major towns of these states by the governments of the affected states especially states under emergency rule. All of these constraints made it difficult for distance learners in such states to easily access their portals or come to the study centres located in these states for any form of assistance. In spite of these challenges, and threat to life by members of the insurgent groups, some distance learners have continued to show interest in their programmes by contacting the centres through various means, and expressed their determination to persist on their programmes until completion.

\section{Theoretical Models of Distance Learners' Persistence on Open Distance Learning Programmes}

In order to establish the theoretical model for this study, the researchers deemed it necessary to define motivation operationally and cite different authors that have worked on distance learners' persistence on Open Distance Learning programmes.

\section{Motivation}

The word motivation has come from the Latin word "movere" which means "to move". According to the Dictionary of Education motivation are reasons or a reason one has for acting or behaving in certain manners or the driving force behind human behaviour. Motivation is an integral factor that arouses, directs, integrates and sustains behaviour towards a goal (Lakshmi, 2010). Motivation is a general term for conditions that cause one to begin an activity and pursue it with vigour and persistence. Note that by this definition, motivation not only instigates behaviour but also operates to reinforce on going behaviour.

Motivation energises the behaviour and interest of the learner. It sustains interest and behaviour for longer 
time. It directs and regulates our behaviour. Motivated state is often described as guided, directed and goal oriented (IGNOU 2009). It is directed towards a selective goal which the individual sets for himself/herself. The motive is terminated by the achievement of goal (Behaviour is selective) Efficiency and adequacy are increased in motivated state of behaviour. Motivation initiates action or behaviour (IGNOU, 2009). For the purpose of this study, the researchers would rely on the definition of motivation as a general term for conditions that cause one to begin an activity and pursue it with vigour and persistence.

There are two broad types: of motivation, intrinsic (internal) and extrinsic (external) motivation.

Intrinsic Motivation: If the individual recognizes an activity as self-rewarding and takes it up then it is called "intrinsic" motivation. The individual takes up the activity because it gives him pleasure or satisfaction.

Extrinsic Motivation: If the motivating force is outside the activity and also outside the person then the motivation is said to be "extrinsic". Engaging in activities for material rewards that they bring is extrinsic motivation. Incentive Extrinsic motivation is related to tangible rewards such as salary and fringe benefits, security, promotion, contract of service, the work environment and conditions of work. Internal motives are considered as the needs that every human being experience, while external indicate the presence of specific situations where these needs arise. It is important to sound a note of caution here; there is no clear demarcation between the two types of motivation since one can metamorphose into another in one situation or the other. That extrinsic motivation can be internalised by the individual if the task fits with their values and beliefs and therefore helps to fulfil their basic psychological needs. From this perspective, extrinsic motivation can be seen at one end fluidly flowing into intrinsic motivation at the end of the continuum.

Extrinsic Motivation $\longrightarrow$ Intrinsic Motivation

However, for the purpose of this study, definitions of intrinsic and extrinsic motivation mentioned above, serves as yardsticks in selection of intrinsic and extrinsic motivators.

Authors like Holder (2007), investigates hope, academics, environment and motivation as predictors of persistence in higher education online programme. The study revealed that flexibility, asynchronous format, time management, self-efficacy, personal growth, self-motivation and support, are important factors that increase motivation to complete a course and promote persistence on distance education programme.

Parker (2003) conducts a study on the predictors of academic persistence in distance education. The study showed that self-efficacy, personal growth and self-motivation promote course completion and persistence on distance learning programme.

While Stanford-Bowers (2008) conducts a study on persistence in online classes: a study of perceptions among community college stakeholders. The result of the study showed that flexibility of the programme, asynchronous format and time management encourage students' persistence on distance learning programme. Muller (2008) in a study on persistence of women in online degree completion reports similar evidence in addition to satisfaction and relevance, self-efficacy, personal growth, self-motivation, social connectedness and support.

Ojokheta (2010) conducts a study on a path - analytic study of some correlates predicting persistence and students' success in distance education in Nigeria. The study showed that quality of interactions and feedback pattern have a direct effect on students' successful completion of online courses. The study also showed linkage of learning environment, motivation, feedback and perception to positive student outcomes.

However, none of the studies reviewed above investigated factors responsible for students' persistence on distance education in an ethno-religious crisis ridden environment. Also with the exception of Ojokheta's (Ojokheta, 2010) study, all the other studies were conducted outside Nigeria. It was in view of the above limitation that this study is designed to find out the determinants for distance learners persistence on distance education programmes in 12 NOUN Study Centres.

\section{Research Questions}

1) What are the intrinsic and extrinsic motivators for distance learners' persistence on their programmes of study in the ethno-religious crisis states in Nigeria?

2) Is there any significant relationship between intrinsic and extrinsic motivators for distance learners' persistence on their programme of study in the ethno-religious crisis states in Nigeria?

\section{Research Hypothesis}

There is no significant relationship between intrinsic and extrinsic motivators for distance learners' persistence 
on their programme of study in the ethno-religious crisis states in Nigeria.

\section{Methodology}

A survey design was adopted for the study. Sample for the study were randomly drawn from NOUN study centres within the 12 states in Nigeria. A total of 2400 samples (male and female) were selected from 12 NOUN selected study centres. The samples were randomly selected from 200 - 400 level distance learners who registered for exams in 2012/2013 academic session. Data for the study was gathered through rating scale using checklist. The students were asked to rank the following determinants in the order of 1 to 24 . The ordinal position of 24 is for the strongest determinant while the least position of 1 is occupied by the weakest determinant.

Intrinsic/Personal Motivators: Desire for personal growth, self-efficacy and self-confidence, self-motivation, faith in God for protection, personal resolve to complete programme, desire to earn a degree, learners' perception of course materials as user friendly, desire for promotion, desire to gain knowledge, self-esteem/sense of belonging, self-actualization and confidence in security agents tackling the security challenges.

Extrinsic Motivators/Support Network: Security provided at the study centre, availability of study materials, and support from study centre staff, support from peers/classmates, support from family/spouse flexibility of the programme, support from work place, Counsellor's Support, technological and media support, tutors response or feedback, institutions' social interaction pattern and conducive learning environment.

The questionnaire requires participants to honestly assign numerical importance of significance (1 to 24 in ascending order) to the perceived motivators that might influence their decisions to persist on their programme of study despite the ethno-religious crisis being experienced with its attendant challenges in their study centres. Data collected was analysed using Descriptive statistics and Pearson Moment Correlation coefficients.

Result: Considering the objectives of this study, the first objective is to establish the mean rank of each motivator. From the result of the study presented in Table 1, respondents' intrinsic motivator of desire to complete their programmes was the most persistent motivator in an ethno-religious crisis states, followed by desire for personal growth and faith in God. Self-efficacy ranked $4^{\text {th }}$, self-motivation ranked $5^{\text {th }}$, desire to earn degree ranked $6^{\text {th }}$, counsellors support ranked $7^{\text {th }}$, supports from the family/spouse ranked $8^{\text {th }}$, supports from the study centre staff ranked $9^{\text {th }}$, desire to gain knowledge ranked 10th, self-actualization ranked $11^{\text {th }}$, supports from peers/course mates ranked $12^{\text {th }}$, desire for promotion ranked $13^{\text {th }}$, self-esteem and sense of belonging ranked $14^{\text {th }}$, flexibility nature of the programme ranked $15^{\text {th }}$, supports from place of work ranked $16^{\text {th }}$, study centres social interaction pattern ranked $17^{\text {th }}$, technological and media supports ranked $18^{\text {th }}$, perception of course material as user friendly ranked $19^{\text {th }}$, confidence in security agents tackling the security challenges ranked $20^{\text {th }}$, availability of study materials ranked $21^{\text {st }}$, tutorial facilitators responses or feedbacks ranked $22^{\text {nd }}$, security provided at the centre ranked $23^{\text {rd }}$ and the extrinsic motivator of study centre conducive learning environment ranked $24^{\text {th }}$ as the least persistent motivator to distance learners in ethno-religious crisis states of Nigeria.

Hypothesis: There is no significant relationship between intrinsic and extrinsic motivators for distance learners persistence on their programme of study in the ethno-religious crisis states of Nigeria.

Table 2 shows that the Correlation is significant at the .05 (2-tailed). The result of .83 indicates a significant positive relationship between intrinsic and extrinsic motivators for the persistence in programme of study between intrinsic and extrinsic motivators among distance learners in the ethno-religious states in Nigeria, therefore rejecting above stated null-hypothesis.

\section{Discussion on Findings}

Considering the objectives of this study which was to determine the intrinsic and extrinsic motivators for distance learners' persistence in their programme of study in the ethno-religious crisis states in Nigeria, it is evident (Table 1) that six intrinsic motivators occupied the first 6 positions in the ranking order of the motivators responsible for distance learner's persistence on their programmes of study in the selected study centres in spite of the ethno-religious crisis. These are the desire to complete the programme, personal growth, faith in God, selfefficacy, self-motivation, and the desire to earn a degree. Evidence from the findings also indicated that, the respondents were intrinsically motivated than extrinsically motivated. It goes to confirm that distance learners who are intrinsically motivated are likely to persist in their programmes of study despite all odds. Distance learners who are intrinsically motivated are more likely to engage in the task willingly as well as work to im- 
Table 1. Description and ranking of intrinsic and extrinsic motivators.

\begin{tabular}{|c|c|c|c|c|c|c|}
\hline Motivators & $\mathrm{N}$ & Minimum & Maximum & Mean & Std. Deviation & Mean Rank \\
\hline Desire for personal growth & 480 & 17.00 & 24.00 & 21.4229 & 2.73657 & $2^{\text {nd }}$ \\
\hline Desire to complete programme & 480 & 17.00 & 24.00 & 21.5333 & 2.66167 & $1^{\mathrm{st}}$ \\
\hline Desire to earn degree & 480 & 18.00 & 24.00 & 20.8938 & 1.74561 & $6^{\text {th }}$ \\
\hline Self-motivation & 480 & 18.00 & 24.00 & 20.9354 & 1.70288 & $5^{\text {th }}$ \\
\hline Faith in God & 480 & 18.00 & 24.00 & 21.0125 & 1.84126 & $3^{\text {rd }}$ \\
\hline Self-efficacy and self-confidence & 480 & 18.00 & 24.00 & 21.0042 & 1.80581 & $4^{\text {th }}$ \\
\hline Desire for promotion & 480 & 9.00 & 17.00 & 12.1583 & 3.01006 & $13^{\text {th }}$ \\
\hline Desire to gain knowledge & 480 & 9.00 & 17.00 & 13.3167 & 2.66339 & $10^{\text {th }}$ \\
\hline Self-esteem and sense of belonging & 480 & 9.00 & 17.00 & 12.1375 & 2.92671 & $14^{\text {th }}$ \\
\hline Self-actualization & 480 & 9.00 & 17.00 & 13.0104 & 2.58426 & $11^{\text {th }}$ \\
\hline Perception of course material as user friendly & 480 & 1.00 & 7.00 & 4.2354 & 2.14816 & $19^{\text {th }}$ \\
\hline Confidence in security agents tackling the security challenges & 480 & 1.00 & 7.00 & 4.1604 & 2.14342 & $20^{\text {th }}$ \\
\hline Counsellor supports & 480 & 15.00 & 19.00 & 16.8333 & 1.59374 & $7^{\text {th }}$ \\
\hline Support from the family/spouse & 480 & 15.00 & 19.00 & 16.7292 & 1.53918 & $8^{\text {th }}$ \\
\hline Support from peers/course mates & 480 & 10.00 & 16.00 & 12.7792 & 2.36033 & $12^{\text {th }}$ \\
\hline Supports from the study centre staff & 480 & 10.00 & 19.00 & 14.6833 & 2.80912 & $9^{\text {th }}$ \\
\hline Flexibility nature of the programme & 480 & 4.00 & 19.00 & 10.3604 & 3.94234 & $15^{\text {th }}$ \\
\hline Support from place of work & 480 & 4.00 & 19.00 & 10.1208 & 3.80610 & $16^{\text {th }}$ \\
\hline Study centre social interaction pattern & 480 & 4.00 & 19.00 & 10.1604 & 3.86209 & $17^{\text {th }}$ \\
\hline Technological and media support & 480 & 4.00 & 19.00 & 9.9104 & 4.03770 & $18^{\text {th }}$ \\
\hline Tutorial facilitators responses or feedbacks & 480 & 1.00 & 7.00 & 3.6729 & 2.02678 & $22^{\text {rd }}$ \\
\hline Study centres conducive learning environment & 480 & 1.00 & 7.00 & 3.5958 & 2.02984 & $24^{\text {th }}$ \\
\hline Security provided at the centre & 480 & 1.00 & 7.00 & 3.6375 & 1.98687 & $23^{\text {rd }}$ \\
\hline Availability of study materials & 480 & 1.00 & 7.00 & 3.7563 & 2.05990 & $21^{\mathrm{st}}$ \\
\hline Valid N (listwise) & 480 & & & & & \\
\hline
\end{tabular}

Table 2. Pearson Moment correlation coefficient analysis $(\mathrm{N}=24)$.

\begin{tabular}{cccc}
\hline Motivators & $\mathrm{N}$ & Pearson (r) & Sig (2-tailed) \\
\hline Intrinsic motivators & 12 & 0.83 & \\
Extrinsic motivators & 12 & & 0.05 \\
\hline
\end{tabular}

prove their skills, which will increase their capabilities (Wikipedia, 2012).

On other hand, extrinsic motivators in this study are the support network, distance learners are suppose to enjoy while studying under distance learning system. As evidenced in this study, extrinsic motivators occupied the last 10 positions (from 15 to 21) in ordinate positions of the ranking though variables like counsellor' supports occupying $7^{\text {th }}$ position, support from the family/spouse occupying $8^{\text {th }}$ position, peers/course mates' support and study centre staff's support occupying $9^{\text {th }}$ and $12^{\text {tnd }}$ position respectively. From the evidence above, it is implicitly clear that the support system in NOUN is neither effective nor efficient nor adequate nor appropriate etc.

Also, as shown in Table 2, though, there is a significant relationship between intrinsic and extrinsic motivators of the respondents in the face of ethno-religious crisis, there is an urgent need to strengthen the support system. This result could be attributed to the ordinate positions of extrinsic motivators such as counsellors' support, support from the family/spouse, support from study centre staff, and support from peers/course In this case, the distance learners could be help to internalise the extrinsic motivators. 


\section{Discussion}

These findings are supported by the findings of previous studies on distance learners' persistence on distance education programme. McGivney (2009) in his study found the desire to complete a programme as an important factor influencing distance learners decision to persist on their studies. Bunn (2004) also reported that personal resolve and determination to succeed and complete a programme, strongly contribute to students' persistence on distance education programme. Link (2006) also found self-efficacy and the desire for personal growth as important factors that aid distance learner's persistence. Other studies which provided evidence on self-efficacy and self-motivation as important factors which aid distance learners persistence, include the studies of Parker (2001), and Ivankova and Stick (2005). Faith in God was also listed by respondents as one of the motivators which influenced their decision to persist on their programme, despite the ethno-religious crisis in their environment. This should be expected from students living in the northern states of Nigeria (the study area) where every happening is given religious interpretation and all successes and failures are attributed to God. Perrella (2000) in his study also found faith in God as one of the important factors which aid distance learners persistence.

Other motivator listed by respondents also include support from family/spouse, support from peers/class mates, support from study centre, flexibility of the programme, desire for promotion and support from work place. Previous studies of Parrella (2000), Comings and Cuban (2002), Bunn (2004), Park and Choi (2009), Holder (2007), Ivankova and Stick (2005), Muller (2008) and Stanford-Bowers (2008) reported similar evidence.

\section{Implications of the Findings to Student Counsellors}

1) Desire for personal growth, self-efficacy, self-motivation and personal resolve to complete a programme and desire to earn a degree, are factors associated with distance learners' personality and if properly developed and encouraged would lead to higher persistence rate among distance learners. Thus the beliefs that students create, develop and hold to be true about themselves are vital forces in their academic success or failures. Students would exercise self-direction and control towards achieving goals and objectives to which they are committed. Student Counsellors should support and encourage distance learners to believe in their own self-efficacy and take responsibility for their own learning.

2) Support from study centres sustain open relationships between distance learners and staff of study centres, especially Student Counsellors, which can reduce stress among distance learners and provide support for persistence and completion of programmes. Therefore Student Counsellors should not only serve as confidantes but should also support and help distance learners develop the values and attitudes needed to persevere in their study, to achieve a high level of academic performance.

3) Support from family members, peers, and workplace and significant others can encourage distance learners to persist on their programmes and achieve programme completion. Fostering coordination and connection among distance learners facilitates cooperative learning and peer helping. Student Counsellors can encourage peer support by establishing study groups or learning circles through which distance learners can share knowledge and provide each other with peer support which also aid persistence among distance learners. Support from work place is also an important factor which aid distance learners' persistence on their programme. As Student Counsellors visit organizations on advocacy, they should solicit for more support from organizations to their staff that are enrolled or wish to enrol into distance education programme of National Open University Nigeria.

\section{Conclusion}

Motivation when applied to learning pushes a student to try to learn or to expand his/her energies in a particular direction. With a desire to learn, there is almost no limit to what a facilitator and learners can accomplish. Without motivation, the effort of a facilitator or staff of study centres in providing opportunities for new experience and understanding to distance learners will amount to nothing.

\section{Suggestions for Further Study}

1) This study needs to be carried out in a more comprehensive manner as soon as the security situation improves. Such a study if conducted may give more comprehensive information on the factors responsible for dis- 
tance learners' persistence on their programme, despite the life-threatening ethno-religious crisis in their learning environment.

2) Similar studies also need to be carried out on how students in ethno-religious crisis-ridden areas in other parts of the world can be assured of their protections at all times by the actions of security agents.

3) Also how the NOUN support system should be strengthened, upgraded, updated and be responsive to the needs of the learners in any situation that they find themselves.

\section{References}

Bunn, J. (2004). Student Persistence in a LIS Distance Education Programme. Australian Academic Research Libraries, 35, 253-270. http://dx.doi.org/10.1080/00048623.2004.10755275

Comings, J., \& Cuban, S. (2002). Sponsors and Sponsorship: Initial Findings from the Second Phase of the NCSALL Persistence Study. Focus on Basics, 6, October.

Holder, B. (2007). An Investigation of Hope, Academics, Environment \& Motivation as Predictors of Persistence in Higher Education Online Programmes. The Internet and Higher Education, 10, 245-260.

Ivankova, N. V., \& Stick, S. L. (2005). Collegiality and Community-Building as a Means for Sustaining Student Persistence in the Computer-Mediated Asynchronous Learning Environment. Online Journal of Distance Learning Administration, 8 , e1-e7.

Lakshmi, M. V. (2010). Adult Education: Unit 7 Psychology of Adult Learning and Motivation. IGNOU. http://www.ignou.ac.in/upload/programme/PGDAE-Prog Guide-SOEDS.pdf

Link, T. (2006). Adult Student Persistence: What Factors Make the Difference. Field Notes for Able Administrators, 2-6.

Muller, T. (2008). Persistence of Women in Online Degree Completion Programmes. International Review of Research in Open and Distance Learning, 9, 1-18.

Ndujihe, C. (2013). Ethno-Religious Violence in 12 States of Northern ,Central States and Abuja. Vanguard Newspaper.

Ojokheta, K. O. (2010). A Path-Analytic Study of Some Correlates Predicting Persistence and Student's Success in Distance Education in Nigeria. Turkish Online Journal of Distance Education, 11.

Park, J. H., \& Choi, H. J. (2009). Factors Influencing Adult Learners’ Decision to Drop Out or Persist in Online Learning. Educational Technology and Society, 12, 207-217.

Parker, A. (2003). Identifying Predictors of Academic Persistence in Distance Education. USDLA Journal, 17, 55-62. http://www.usdla.org/html/journal/JAN03_issue/article06.html

Parrella, A. (2000). Focus on Teaching Supports and Hindrances: A Force-Field Analysis. Focus on Basics, 4, March.

Stanford-Bowers, D. E. (2008). Persistence in Online Classes: A Study of Perception among Community College Stakeholders. Journal of Online Learning and Teaching, 4, Retrieved from:

http://jolt.merlot.org/vol4no1/stanford-bowers0308.pdf 
Scientific Research Publishing (SCIRP) is one of the largest Open Access journal publishers. It is currently publishing more than 200 open access, online, peer-reviewed journals covering a wide range of academic disciplines. SCIRP serves the worldwide academic communities and contributes to the progress and application of science with its publication.

Other selected journals from SCIRP are listed as below. Submit your manuscript to us via either submit@scirp.org or Online Submission Portal.
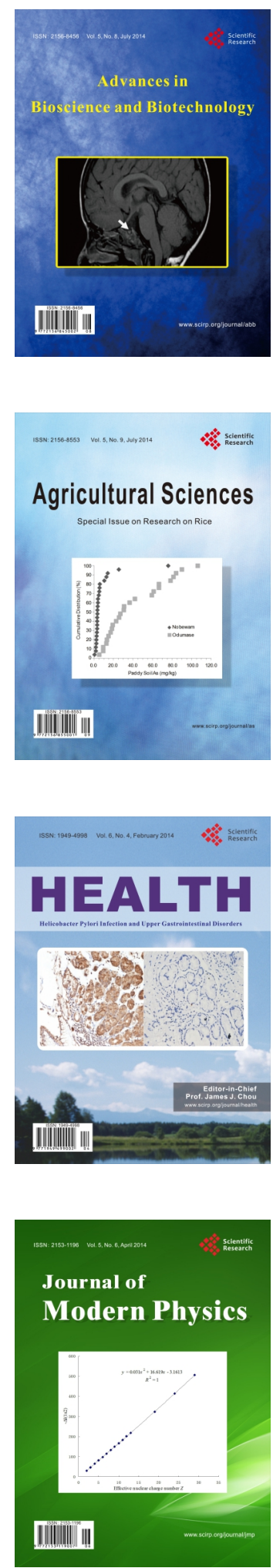
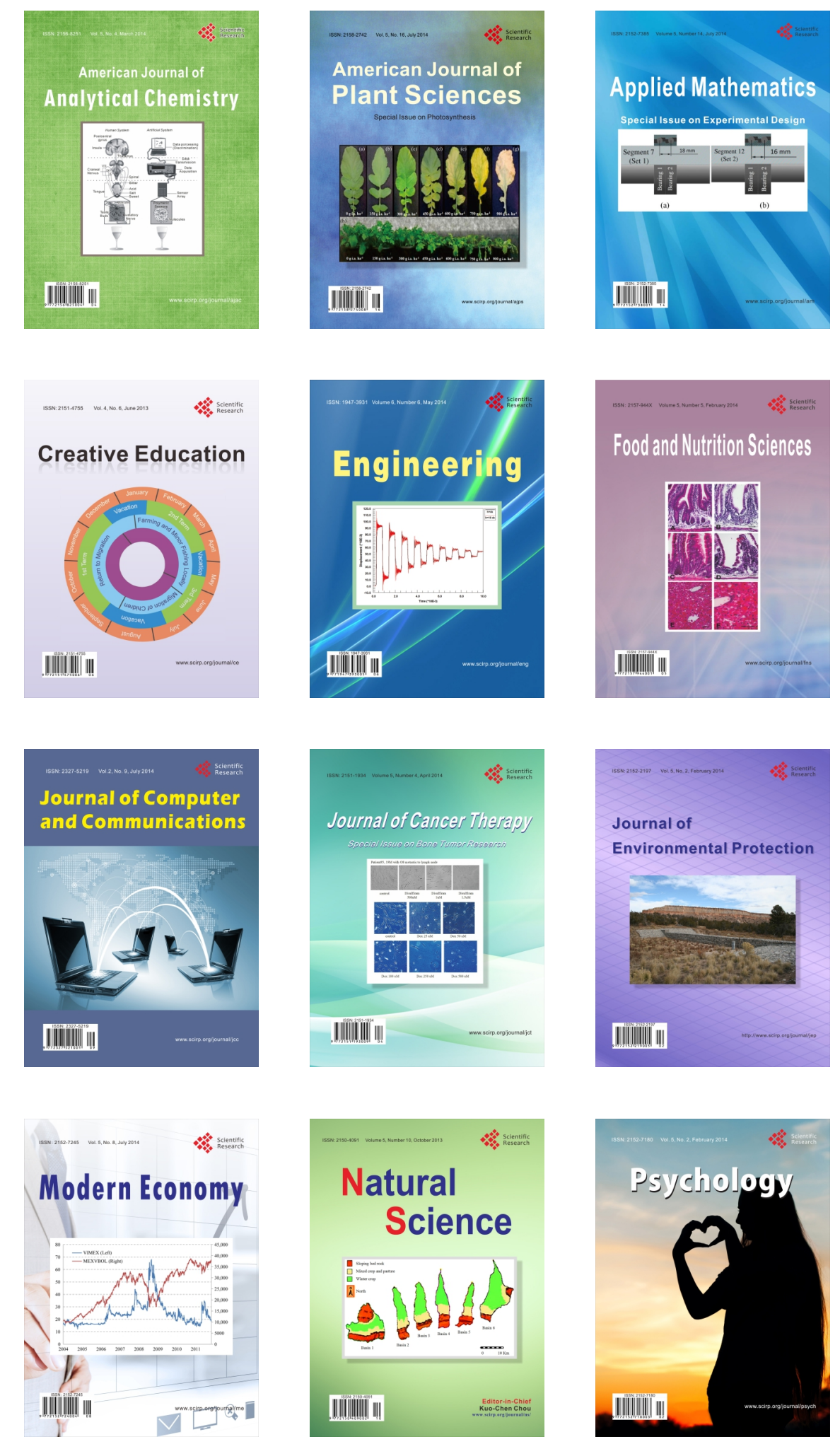